\title{
The Case of South African and Chilean Health Systems: Comparison of Financial, Economic and Health Indicators
}

\author{
A Coustasse, P Hilsenrath, P Rojas
}

\section{Citation}

A Coustasse, P Hilsenrath, P Rojas. The Case of South African and Chilean Health Systems: Comparison of Financial, Economic and Health Indicators. The Internet Journal of World Health and Societal Politics. 2004 Volume 2 Number 2.

\begin{abstract}
The purpose of this study is to identify similarities and differences between healthcare systems of South Africa and Chile. The World Health Report 2000, the Human Development Index, and financial indicators were used for comparison. Chile showed better performance than South Africa in most of the measures used. Significant progress has been made in South Africa, bringing better education, healthcare and housing to the deprived black majority. However, the HIV/AIDS epidemic, weighs heavily on health indicators. Chile decentralized its health services and implemented economic reforms during the 1980' and has had steady improvement in its healthcare indicators. Finally, these counties share: World Bank classification as middle income economies, dual public/private health systems, skewed income distribution and allocation towards the private sector, with relatively high private health expenditures as a percentage of total health expenditures, focus in primary health care in their public health system and implementation of new healthcare reforms.
\end{abstract}

Figure 1

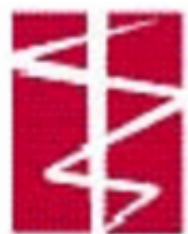

\section{UNIVERSITY of NORTH TEXAS HEALTH SCIENCE CENTER at Fort Worth Education, Research, Patient Care and Service}

\section{INTRODUCTION}

The health care systems of two middle income countries, South Africa and Chile are reviewed, with special attention given to their history, health financing, proportion of public and private health expenditures, inequities, human development, and the performance of these countries in the WHO report 2000. Although South Africa is a middleincome country, large sections of the population are povertystricken and suffer from poor health. The Chilean health care system is a predominantly public health system with a strong and sizable private system. In 2001, sixty three (63) percent of the population was covered by the public sector, while 37 percent was covered by the private sector, which included 23 percent private commercial health insurance and the remaining 14 percent was covered by the Chilean Worker Compensation plan, other private plans, such as the armed forces health systems and the Chilean Veteran Affairs (V.A) system $\left({ }_{1}\right)$. The South African health system is also mixed with provincial health services providing care, to a majority of the population and a state of the art private sector accounting for the $59 \%$ of expenditures despite covering only 18 percent of the total population $\left(_{2}\right)$.

The purpose of the paper is to identify similarities and differences between health care systems of South Africa and Chile and policy insights from studying these two countries.

\section{HISTORICAL OVERVIEW OF HEALTH CARE SYSTEMS IN SOUTH AFRICA AND CHILE SOUTH AFRICA}

The contemporary South African health system can be traced to The Public Health Amendment Act of 1946 demarcating the functions of the central government and the provinces. The provinces were made responsible for hospital and other health services ${ }_{3}$ ). In the apartheid era (1948-1994) the health sector was hospital-based; hospitals were concentrated in white areas and there were major efforts to introduce managed care in the health system.

Desegregation of public hospitals in the late 1980s and early 
1990s, associated with elimination of apartheid led to a dramatic increase in the number of private hospitals as wealthy patients lost confidence in public hospitals. When the African National Congress assumed power, the dismantling of the country's race-based health system was accelerated and a major reform was started switching towards a system focused on primary health care to ensure local-level control of public health services. Since 1994, the delivery of both hospital and primary health care delivery has been provided by the nine provincial health administrations that were created with the transfer of power to majority government. A portion of the budgets of these provincial health administrations was transferred to local authorities that also render primary health care services. Currently there is free health care for children under six, and for pregnant or breastfeeding mothers in the whole country $(4)$.

Significant changes have occurred since 1994 in the financial arrangements of the government. These have included introduction of a federal fiscal system affecting the financing and budgeting of virtually all of the significant social services, including health, social development and education .This has helped redistribute resources in a more equitable manner. The public health care sector depends on general tax revenues, but local government own revenue also contributes some of it. Extensive new legislation regarding national health has been enacted to expand access to health care within a district based system of primary health care, nationalization of health laboratories services, compensation for occupational injuries and diseases, greater regulation of health professionals and health promotion.

The National Health Act of 2003, established a broad framework for administration of the health care system, with delineation of powers and functions among national, provincial and district health authorities; protected the rights of health users; addressed the establishment and operation of private and public health facilities; the regulation of public health programs and services; health laboratories and health surveillance among others.

\section{CHILE}

Chile has developed a primary health care approach based on the community and the family health. The Chilean system of health has a long organizational tradition. Its origns go back to 1552, with the foundation of the first hospital, called San Juan de Dios, in Santiago, the capital $\left(_{5}\right)$. Later, hospitals were created and financed by the Public Charity, and those that were administered by different religious orders of the Catholic Church. The Public Charity, a non-profit organization, administered these until 1850. Financing was obtained mostly by donations and especially by legacies of inheritances. In 1875, a non-profit private organization, the National Commission of Public Charity was constituted $\left({ }_{6}\right)$. This organization developed hospital infrastructure until 1952, and was merged with the National Worker Medical Service (SERMENA), which started in 1942, to cover preventive medicine for blue-collar workers ${ }_{6}$ ), and with the central government, which provided the network of physician's offices and other public institutions, to form the National Service of Health (SNS). This created a single organization in charge of urban doctor's offices, rural medicine and hospitals of four different complexity levels. Hospitals of greater complexity were established in each of the 13 regions of the country and national centers of the most complex pathologies such as oncology, infectious diseases, lung surgery, neurosurgery and traumatology were created and centralized in the capital during the 1950' and the beginning of the 1960 ' $\left.{ }_{7}\right)$. Public health programs were created, implemented and controlled through preventive and primary care medicine. Reforms under the Pinochet government (1973-1991) introduced radical changes into social security and health systems, leading to the creation of private institutions for pension fund (Pension Fund Administration-AFP) and private health insurance sector (ISAPRES). Decree-Law 3,500 was published in November 1980, establishing a new system of old-age, disability and survivorship pensions based on workers' savings and their capitalization in individual accounts. The new pension system incorporates the concept that the workers who are enrolled in the system actually own their social security savings, stressing the close relationship between the effort made by a person to save throughout his or her active life and the old-age, disability and survivorship benefits that he or she receives. It also introduces the management of savings by private companies (AFPs), which have a single corporate purpose and the role of providing social security benefits and services. The model has been copied and implemented in 12 Latin American countries including Chile and 25 around the world $\left(_{8}\right)$.

Since 1981, Chile's formal sector workers must by law allocate 7 percent of their monthly salary to finance health insurance. They are free to choose between public or private insurance (ISAPRES). In addition, reforms at the central government aimed mainly the decentralization of the system 
with the termination of the SNS, and creation of the National System of Services of Health (SNSS), which had the same functions with 29 regrouped regional health services ${ }_{5}$ ). The Municipal governments, on the other hand, took care of most of the primary care centers of the country taking responsibility of infrastructure and personnel for the delivery of primary health care. This occurred in stages, beginning in 1980, and approximately 30 percent of physician's offices completed by 1989, under Juan Giaconi, last minister of the military government. A National Health Fund (FONASA) was created from the merger of SERMENA and the finance department of the SNS, to manage the resources of the public health sector.

During the democratic governments period (1990 to 2004), the public sector-particularly in the secondary and tertiary levels, - increased its total and per beneficiary spending and investment, primarily through increased allocations within the national budget $\left({ }_{9}\right)$, which were restricted in the military government. Furthermore, there has been significant improvement in social and economic indicators, with a reduction in poverty levels from $39.3 \%$ in 1990 to $20.6 \%$ in 2000 , and an increase in per capita GDP of $46.9 \%$ between 1991 and $1999\left(_{1}\right)$. In addition, in 2004, a new reform to the health sector was approved by the congress. The main feature of the new reform is called Universal Access with Explicit Guarantees (AUGE). For the public subsystem, it gives explicit guarantees to treat specific diseases included in the plan, although waiting comprise this entitlement. It also will allow public hospitals to buy private services to cover the benefits that are provided with their own resources and this is expected to reduce the length of waiting lists. For the private subsystem, co-payments, have been limited and will be made more transparent to patients $\left({ }_{10}\right)$.

\section{PROFILE OF SOUTH AFRICAN AND CHILEAN HEALTH STATUS \\ HEALTH INDICATORS}

South Africa and Chile are regarded, in terms of World Bank classification, as middle-income countries. South Africa is the $4^{\text {th }}$ largest country in the WHO African region with a population of almost 44.8 million (Table 1). The Infant Mortality Rate (IMR) in 2001 was 56 deaths per 1000 live births $\left(_{11}\right)$. For 2002, child mortality (deaths under the age of 5 years per 1000 births) was 86 for males and 81 for females. Life expectancy at birth in 2002 was 50.7 for the total population, and was estimated at 48.8 years for males and 52.6 years for females $\left({ }_{12},{ }_{13}\right)$. While in Chile, HIV/AIDS is a minor problem, in South Africa in 2001 approximately 20 percent of the population from 15 to 49 years of age was HIV positive (Table 1). While the infant mortality rate has declined since 1980, racial disparities in infant mortality have widened. This has been due to unavailability of maternal care for African women. The IMR for Africans was 5.3 times higher than that for Whites in 1980 and 7.4 times greater by $1994\left({ }_{14}\right)$ and this has to do with racial disparities of AIDS too.

\section{Figure 2}

Table 1: Health Indicators of South Africa and Chile: Most Recent Years

\begin{tabular}{|c|c|c|}
\hline Health Indic ators & South Africa & Chile \\
\hline $\begin{array}{l}\text { Population estimates } \\
\text { Total population }\end{array}$ & $44,759,000$ & $15,613,000$ \\
\hline $\begin{array}{l}\text { Life expectancy at birth (years)* } \\
\text { Total population } \\
\text { Males } \\
\text { Females }\end{array}$ & $\begin{array}{l}50.7 \\
48.8 \\
52.6 \\
\end{array}$ & $\begin{array}{l}76.7 \\
73.4 \\
80.0 \\
\end{array}$ \\
\hline $\begin{array}{l}\text { Child mortality rate (deaths per } 1000 \text { live } \\
\text { births)" } \\
\text { Males } \\
\text { Females }\end{array}$ & $\begin{array}{l}86 \\
81\end{array}$ & $\begin{array}{l}16 \\
13\end{array}$ \\
\hline $\begin{array}{l}\text { Infant mortality rate (deaths per } 1000 \text { live } \\
\text { deaths) }\end{array}$ & 56 & 10 \\
\hline $\begin{array}{l}\text { People living with HIVIAIDS } * \\
\text { Adults (\% age 15-49) } \\
\text { Women (age 15-49) } \\
\text { Children (age 0-14) } \\
\text { Prevalence of HIV ( } \% \text { ages } 15-24 \text { )** }\end{array}$ & $\begin{array}{l}20.1 \\
2,700,000 \\
250,000 \\
25.6 \\
\end{array}$ & $\begin{array}{l}0.3 \\
4.300 \\
<500 \\
0.3\end{array}$ \\
\hline
\end{tabular}

Chile's total population according to the latest census of 2002 was 15.6 million and was ranked $9^{\text {th }}$ compared with other countries in the WHO region of the Americas $\left({ }_{15}\right)$. Half of the population is concentrated in two of the Chile's 13 political and administrative regions- Valparaiso and Metropolitan Santiago, which represent only 4 percent of the national territory $\left({ }_{17}\right)$. Chile's mortality rates have declined in recent decades $\left({ }_{1}\right)$.Global health indicators, like life expectancy and infant mortality, have consistently improved in Chile in recent decades. Infant mortality decreased from 32 per 1000 live births in 1980 to 10 per 1000 live births in $2001\left(_{11}\right)$; life expectancy increased from 67 years in 1980 to 76.7 years in 2002 , and general mortality diminished from 6.6 per 1000 persons in 1980 to 5.0 in $2002\left(_{18}\right)$. Child mortality was 16 per 1000 live births for males and 13 per 1000 live births for females (Table 1). Comparing the two countries health indicators there is an overwhelming difference mostly because AIDS/HIV devastation.

\section{THE HUMAN DEVELOPMENT INDEX}

The Human Development Index (HDI) is a socio-economic indicator, which measures the average achievements in a country in three basic dimensions of human development - 
life expectancy, educational attainment and real GDP per capita. While the concept of human development is much broader than any single composite index can measure, the HDI offers a powerful alternative to income as a summary measure of human well-being.

Chile was ranked higher than South Africa in terms of HDI (Table 2). The reason for Chile's superior HDI ranking is its profound success in economic, demographic, and epidemiological outcomes in recent decades, based on health policies to decrease infant mortality, address

malnourishment and the TB program as well as many others programs. This correlates with an overall improvement in health status of the population. However, inequalities still persist in Chile, and the HDI ranking reflects it. In 2002, Chile was ranked 43, in the high human development category, in third place in Latin America after Barbados $\left({ }_{29}\right)$, and Argentina $\left({ }_{11},{ }^{34}\right)$.

South Africa is in the medium human development category , ranked 119, which is an expression of profound deterioration of heath status associated with HIV/AIDS, especially life expectancy at birth of 48.8, and a relative low adult literacy rate of 86 compared to Chile (Table 2).

\section{Figure 3}

Table 2: Human Development Indicators of South Africa and Chile, 2004

\begin{tabular}{|l|l|l|}
\hline Key Indicators & South Africa & Chile \\
\hline $\begin{array}{l}\text { Human development } \\
\text { index (HDI) ranking * }\end{array}$ & 119 & 43 \\
\hline $\begin{array}{l}\text { GDP Per capita (US \$. } \\
\text { 2002) PPP** }\end{array}$ & 10,070 & 9,820 \\
\hline $\begin{array}{l}\text { Adult literacy Rate (\% } \\
\text { age 15 and above) * }\end{array}$ & 86 & 95.7 \\
\hline $\begin{array}{l}\text { Combined primary, } \\
\text { secondary and tertiary } \\
\text { gross enrollment ratio } \\
>25 \text { years (\%) 2001-02* }\end{array}$ & 77 & 79 \\
\hline $\begin{array}{l}\text { Life Expectancy (years, } \\
\text { HDI)* }\end{array}$ & 48.8 & 76 \\
\hline
\end{tabular}

HIV/AIDS was thrust upon a country that, in its new birth of democracy, was addressing several challenges, which included redressing the imbalances of its past. In 12 years, HIV prevalence in 15-49-year-old rose from less than $1 \%$ to about $20.1 \%$ in 2001 . There were 360,000 deaths due to this disease in 2001. Finally, the HIV epidemic that has swept through South Africa has now developed into a maturing AIDS epidemic. In many communities around the country, households are battling to cope with caring for a severely ill household member, while dealing with the economic consequences of the person's illness. There has been a sharp increase in orphans and poor social network to cure for them. There is no doubt that health services are feeling the impact of this epidemic, and this is likely to get worse in the next 5 to 10 years $\left({ }_{19}\right)$.

\section{HEALTH SPENDING AND FINANCE}

Table 3 provides the National Health Account indicators of South Africa and Chile. South Africa allocated 8.7 percent of GDP to health care in 2001, an unusually high proportion by international standards. The equivalent average figure for middle-income countries was 5.7 percent and South Africa was ranked first for the WHO African Region. The total expenditure on health as a percent of GDP in Chile was 6.8 percent in 2001. Per capita total expenditure on health in international dollars for South Africa was $\$ 887$ and $\$ 667$ for Chile (Table 3).

\section{Figure 4}

Table 3: National Health Account Indicators of South Africa and Chile, 2001

\begin{tabular}{|c|c|c|}
\hline Selected National Health Account Indicators (2001) & $\begin{array}{l}\text { South } \\
\text { Africa }\end{array}$ & Chile \\
\hline $\begin{array}{l}\text { Total Health Expenditure } \\
\text { Total expenditure on health care as \% of GDP, 2001* } \\
\text { Public health expenditure ( } \% \text { of GDP), } 2001 ; \\
\text { Private health expenditure ( } \% \text { of GDP), } 2001^{*} \\
\text { Per capita total expenditure on heatth (PPP, US\$), } 2001\end{array}$ & $\begin{array}{l}8.7 \\
3.6 \\
5.1 \\
887\end{array}$ & $\begin{array}{l}6.8 \\
2.9 \\
3.9 \\
667\end{array}$ \\
\hline $\begin{array}{l}\text { Public Health expenditure } \\
\text { General government expenditure on health as } \% \text { of total expenditure on } \\
\text { health" }\end{array}$ & 41.4 & 44 \\
\hline Private health expenditure & & \\
\hline $\begin{array}{l}\% \text { of population covered by private expenditure *- } \\
\text { Private expenditure on health as percent of total expenditure on health* }\end{array}$ & $\begin{array}{c}18 \\
58.6\end{array}$ & $\begin{array}{c}23 \\
56.0\end{array}$ \\
\hline \multicolumn{3}{|l|}{ Sources of private health expenditure } \\
\hline Prepaid plans as percent of private expenditure on health.t. & 72.2 & 40.3 \\
\hline $\begin{array}{l}\text { Out-of-pocket expenditure on health as percent of private expenditure } \\
\text { on health" }=\end{array}$ & 22.1 & 59.6 \\
\hline
\end{tabular}

Source: "Figures are for 2001, United Nations, Human Development Report, 2004. " PAHO, 2002. $\cdots$ World Bank, 2003.

General government expenditure on health as percentage of total expenditure on health of 41.4 percent and 44 percent, in South Africa and Chile respectively, shows spending skewed towards the private sector in both counties. A striking 58.6 percent and 56 percent of expenditures takes care accommodates only 18 percent and 23 percent of the private South African and Chilean population respectively $\left({ }_{11}\right)$. In 2001, prepaid plans, as a percentage of private expenditure on health, were relatively high in South Africa with 72.2 percent compared to 40.3 percent in Chile. Surprisingly Chile had more than twice the out of pocket expenditures with 59.6 percent compared with 22.1 percent of South Africa. This finding is aligned with the fact that the most common complaint from the ISAPRES is their lack of transparency of their plans with high out-of-pocket expenditure, which will be addressed with the new 2004 
health reform.

In South Africa government financed care is utilized by the majority of the population. Health funding for public health services is drawn primarily from general revenues $\left(_{19}\right)$. Individuals commonly pay out of pocket including copayments. Employers are the third major source of health care financing and they commonly provide private insurance for well paid workers. The new government can be proud of its economic achievements with stabilization of the economy, substantial economic growth. In addition the government has provided access to clean water for 9 million people, built 1.5 million houses and installed electricity and telephone connections to more than 1 million homes $\left(_{4}\right.$ ).

South Africa's vision for health care is a decentralized system that offers an equally accessible and free basic package of primary health care to all of its citizens. After four decades of minority apartheid rule, a democratic government was established in $1994\left(_{20}\right)$. Social health insurance in South Africa must vie with a strong private sector that opposes reforms for nationalization of private providers $\left({ }_{21}\right)$. Since 1994, when the African National Congress (ANC) assumed power, the dismantling of the country's race-based health system began. Previously, hospitals were assigned to particular racial groups with a concentration in white areas. With 14 different health departments, the system was characterized by fragmentation and duplication. There was no real attempt to deliver equitable health services to the majority of people, and the health sector was largely focused around hospitals. Those living in rural areas had to travel long distances for medical care. A district-based health system has being developed to ensure local-level control of public health services, and to standardize and coordinate basic health services around the country to ensure that health care is affordable and accessible to everyone. More than 700 clinics have been built, 2,298 clinics upgraded and given new equipment, and 125 new mobile clinics introduced. There are now more than 3500 clinics in the public sector. Free health care for children under six, and for pregnant or breastfeeding mothers, is also available at these facilities $\left(_{22}\right)$. The number of private hospitals and clinics continues to grow as wealthier patients shift from public to private providers. In 2000 there were 161 private hospitals, with 142 of these in urban areas. Now in 2004, there are 200. The mining industry also provides its own hospitals, and has 60 hospitals and clinics around the country $\left({ }_{22}\right)$.
Chile has developed a primary health care approach based on preventive and family medicine. Chile's public health sector is oriented toward primary health care, public health and equity. Chile's public sector has decentralized to enable increased autonomy of primary care centers from referral facilities. This has improved health services by minimizing the length of time patients have to wait to see their physicians.

Since WWII, national programs of 1) mandatory immunization 2) health education and promotion, 3) "the healthy boy control program" 4) undernourishment, program for pregnant woman, with professional attention for delivery, including control of the new born, family planning, and 5) programs for acute and chronic diseases like tuberculosis, sexual transmitted diseases, diabetes, hypertension and many others, were continued and/or expanded and have allowed Chile to improve its indicators relative to its economic level.

In Chile, there is a single public health insurer and insurance is provided to citizens through FONASA. The private system is made up of: prepaid plans or Instituciones de Salud Previsional (ISAPRE), that provide private health insurance. Special social insurance funds exist for the Armed Forces health system, the VA system and the Chilean workers compensation plan.

The FONASA provides health insurance coverage to almost two-thirds of the population, whereas ISAPREs covers 3 million beneficiaries, close to one-fifth of the population. FONASA is the government's health financing agency that pays for provision of public health and investments and operations of public hospitals and municipal health centers. About one-half of FONASA revenue comes from the public treasury, while the other half comes primarily from the 7 percent payroll contributions made by FONASA formal sector households. FONASA provides insurance to four groups according to economic status of the population. Category A and B are inactive or unemployed and lowincome workers respectively. Category $\mathrm{C}$ and $\mathrm{D}$ groups provide coverage to high-income people. In 1990, of those covered by FONASA, 38.8 percent were category A, 30.6 percent category B, 9.2 percent category $C$, and 9 percent category D. Category A and B have access to services provided by public hospitals and clinics (hospitals provide secondary and tertiary care; clinics provide health care on a first-come, first-served basis). People under category $\mathrm{C}$ and D have the option to use private health providers $\left({ }_{5},{ }_{7}\right)$. 


\section{HEALTH CARE INEQUALITY SOUTH AFRICA}

The apartheid era left a legacy of inequality in South Africa, both in relation to income distribution and access to social services. A range of documents highlighted the substantial inequities within the health sector at the time of the democratic elections in 1994. But South Africa is still characterized by large inequalities in health status and access to health services $\left({ }_{23}\right)$. The complex pattern of inequality in South Africa is demonstrated by consideration of an indicator such as the proportion of women delivering without a trained attendant. According to the Demographic and Health Survey (DHS), 14.2 percent of all births in the five years preceding the survey had been delivered without help of a medically trained attendant. Similar patterns were observed when comparing the type of trained attendant available. Most Black Africans rely on the public health service, whereas Whites and Indians Africans rely almost entirely on private care. Cost of health care, distance, availability and cost of transport are major barriers to care for Africans. Most South Africans do not report for their first treatment at a public clinic, but choose either a public hospital or private doctor. This is most likely a function of the inaccessibility and scarcity of clinics, particularly in rural areas, restricted clinic opening times and perceptions that the standard of care in clinics is worse than in public hospitals. For example, 71.9 percent of births to women in the richest quintile had been delivered by a doctor compared to only 14.7 percent of deliveries in the lowest quintile. However, there is some variation in the average number of antenatal visits between groups. For example, Black women had an average of 5.7 antenatal visits compared to 9.9 and 9.5 for Indians and White African mothers respectively. A woman in the poorest quintile attended antenatal visits an average of 5.2 times compared to 8.6 visits for the richest quintile $\left({ }_{24}\right)$.

Finally, there is a huge inequality of the income distribution, with the top quintile of the population receives $66.5 \%$ of the income while the bottom quintile receives only $2 \%\left({ }_{11}\right)$.

\section{CHILE}

In Chile there are differences between rich and poor communities. For example, life expectancy at the county level demonstrates that male life expectancy at birth ranges over a span of 19.6 years, from 66.1 to 85.7 years according to the socioeconomic condition of the county. For females, life expectancy ranges over a span of 11.4 years from 73.3 to 84.7 years from poor communities to rich ones. The infant mortality rate also changes according to the educational level of the parents being 5 times higher in those infants born from mothers with less than 8 years of education as compared with those born from mothers with 12 or more years $\left({ }_{25}\right)$.

A socioeconomic survey (CASEN, 2000) showed at the end of 2000, 10 percent of the wealthiest households captured 40.3 percent of income, while the poorest 10 percent obtained just 1.7 percent. In the 1998, 70 percent of the country households had an income below the national average. The CASEN study found differences among counties were even more extreme in housing quality, potable water supply, and sewer systems $\left({ }_{1}\right)$.

Chileans with low income can get free treatment at public hospitals. In general, services and facilities offered in the public hospitals are not as advanced as those in the private sector. Furthermore, Chileans living in some of the more isolated rural areas of the country cannot get to the more advanced health facilities, which are generally located near the urban centers. The government has been trying to deal with inequalities in the health system through better management of the public health care system. It is making efforts to ensure equal access to health services and to upgrade public health care facilities.

Regarding distribution of the income the top quintile of the population receives $62.5 \%$ of the income while the bottom quintile receives only $3.3 \%\left({ }_{11}\right)$.

\section{WORLD HEALTH ORGANIZATION (WHO) WORLD HEALTH REPORT 2000 OF MEMBER COUNTRIES: RANKING OF CHILE AND SOUTH AFRICA}

In 2000, the WHO developed a methodology to rank the health systems of the world that included five broad categories: the overall level of health; the distribution of health in the population; the overall level of responsiveness; the distribution of responsiveness; and the distribution of financial contribution. For each of these parameters, WHO report 2000 used existing or newly generated data to calculate measures of attainment for 191 member countries where information could be obtained $\left({ }_{26}\right)$.

Chile was ranked $33^{\text {rd }}$ out of 191 countries with respect to overall performance of its health care system and $23^{\text {rd }}$ with regard to performance on the health level. South Africa was ranked $175^{\text {th }}$ out of 191 countries with respect to overall 
performance of its health care system and $182^{\text {nd }}$ with regard to performance on the health level. Because rich countries generally enjoy good health, and because high incomes allow for large health expenditures, the ranking by overall health performance is closely related to income and health spending. However, the large weight given to distributional goals explains why, for example, Japan outranks the United States and why Chile, Colombia and Cuba outrank all other Latin American countries $\left({ }_{27}\right)$.

Table 4 shows the performance of both South Africa and Chile in these five parameters and the ranking with respect to the other 191 WHO countries. The responsiveness level for South Africa is average compared to most of the countries. This could be due to the relatively advanced private sector. Table 4 shows that the health system of Chile is more responsive to the health needs of the people. South Africa was better than Chile in fairness in financial contribution (142-143 vs. 168). This indicator measures the ratio of total spending on health to its permanent income above subsistence which suggests that the burden in the very poor is higher in Chile. However, this country was ranked $1^{\text {st }}$ in health distribution due to Chile's highly even distribution of equality child survival, an indicator perhaps of successful primary care programs.

\section{Figure 5}

Table 4: WHO Health Report 2000: Measures, Weights, and Ranks, Selected Countries

\begin{tabular}{|l|l|l|l|l|}
\hline Measure & Weight & WHO \#1 & Chile & $\begin{array}{l}\text { South } \\
\text { Africa }\end{array}$ \\
\hline $\begin{array}{l}\text { Health: level } \\
\text { (DALE) }\end{array}$ & 0.25 & Japan & 23 & 160 \\
\hline $\begin{array}{l}\text { Health: } \\
\text { distribution }\end{array}$ & 0.25 & Chile & 1 & 128 \\
\hline $\begin{array}{l}\text { Responsiveness: } \\
\text { level }\end{array}$ & 0.125 & U.S & 45 & $73-74$ \\
\hline $\begin{array}{l}\text { Responsiveness: } \\
\text { distribution }\end{array}$ & 0.125 & $\begin{array}{l}\text { United } \\
\text { Arab } \\
\text { Emirates }\end{array}$ & 103 & 147 \\
\hline $\begin{array}{l}\text { Faimess in } \\
\text { financial } \\
\text { contribution }\end{array}$ & 0.25 & Colombia & 168 & $142-143$ \\
\hline $\begin{array}{l}\text { Overall goal } \\
\text { attainment }\end{array}$ & 1 & Japan & 33 & 151 \\
\hline $\begin{array}{l}\text { Health expend. } \\
\text { per capita PPP } \\
\text { USS NA }\end{array}$ & US & 44 & 57 \\
\hline $\begin{array}{l}\text { Performance: on } \\
\text { level of health }\end{array}$ & NA & Oman & 23 & 182 \\
\hline $\begin{array}{l}\text { Performance: } \\
\text { overall health- } \\
\text { system } \\
\text { performance }\end{array}$ & NA & France & 33 & 175 \\
\hline
\end{tabular}

Source: World Health Organization (2000). The World Health Report 2000 Health Systems: Improving Pertormance.

\section{DISCUSSION}

This paper analyses the health care infrastructure of both South Africa and Chile. Chile was ranked higher than South
Africa in most of the parameters by World Health organization (WHO). The overall health system performance of Chile in the WHO report was better than South Africa. This could be due to a combination of factors which include: the apartheid system in South Africa, which for decades provided more and better services to whites than the nonwhites and the impact of HIV and AIDS which has reduced life expectancy and had a significant economic impact on South Africa in the recent years.

South Africa, with a history of civil conflict and high prevalence of HIV and AIDS, was less efficient. In many different ways, the devastation of AIDS among individuals and families ultimately affects a country's overall economic performance and can explain the low life expectancy in the country. The loss of experienced workers and skilled professionals reduces production in key sectors in both health sector and financially. It is expected that 40 to $50 \%$ of South Africa's workforce could die from AIDS over the 10 years and that by 2005 there will be about 800,000 orphans under the age of 15 years $\left({ }_{28}\right)$. Poverty is still widespread and income disparities remain, as tight budgetary policies complicate efforts to improve living conditions.

On the other hand, Chile has experienced sustained economic growth from the neo-liberal model implemented during the military government and maintained by the democratic governments after 1990. The Chilean economic model has been cited as an example of development to be followed by other nations because the nation's strong and sustained economic growth in the 1980s and 1990s (6.3 percent per year average annual GDP growth rate in 1989-2000) $\left.{ }_{17}\right)$. Levels of health are not solely affected by health systems. The most widely accepted other determinant is education, which is strongly associated with the health of both children and adults in developed and developing countries $\left({ }_{29}\right)$. Higher GDP per capita in Chile has facilitated provision of public health measures (such as clean water, improved nutrition, sanitation and vaccinations) and personal consumption patterns (such as adequate diet) that are inputs into the public and household production of health. In addition there has been reduction in poverty levels from 39.3 percent in 1990 to 20.6 percent in 2000 and an increase in per capita GDP of 46.9 percent between 1991 and $1999\left(_{1}\right)$.

The role of pre paid plans in Chile has been controversial. For supporters, the ISAPRE's system attracted a significant number of middle-income workers to leave the state-run 
system, thus permitting the public system to concentrate on the most in need $\left(_{30}\right)$. Others think the development of the private sector created direct competition with social insurance and publicly funded provision, and the ISAPREs has focused on providing insurance for high frequency, low cost services, intended for high income and low health risk groups. It is also argued that these prepaid plans drop their high risk and older populations, so their only choice is to return to FONASA. Barrientos in 2000 reported 6.7 percent of those 65 or more belonged to the ISAPRE system, while 80.4 of this population belonged to FONASA. The new 2004 reform should correct deficiencies in both sectors, and lead to more complementary relationship ${ }_{7}$ ).

South Africa has one of the highest shares of GDP allocated to health among middle-income countries. But overall performance of South Africa when compared to most of these countries is very poor. The main reason is due in part to the devastating effect of HIV and AIDS in South Africa. South Africa spends a total of US \$ 33.3 million on HIV/AIDS programs, which translates into $\$ 0.78$ per capita. In South Africa, the AIDS epidemic is not just a health crisis. It is also a major threat to development and to human society. UNAIDS has estimated that when HIV prevalence rates rise to more than 20 per cent, gross domestic product (GDP) in those countries can be reduced by as much as 2 per cent a year $\left({ }_{31}\right)$. In South Africa, the investment bank ING Barings has projected that HIV/AIDS could drag down GDP by $0.3-0.4$ percent a year. Another study has indicated that by the end of the decade, AIDS could have decreased South Africa's GDP by 17 per cent, or US \$22 billion.

A major concern in addressing the impact of the HIV/AIDS epidemic is the high cost of anti-retroviral drugs programs. This requires commitment to address pricing structures by major multi-national pharmaceutical companies, as well as the mobilization and provision of new and additional resources to assist developing countries to access medical interventions against HIV and AIDS. Pfizer, the American Pharmaceutical Company has offered the South African government, free antiretroviral drugs to combat the AIDS epidemic. But an effective national AIDS program has yet to be established.

What has been a shame was the weak response to the AIDS epidemic by the ANC. Government measures have been inadequate and ineffective, example of this is that only $56 \%$ of the healthcare facilities have HIV testing available $\left({ }_{32}\right)$. Even worse was the denying from president Mbeki, of the link between HIV infection and AIDS in the face of overwhelming evidence provided by the global scientific community $\left({ }_{33}\right)$, until a deal was reached with the drug companies for the antiretroviral treatment and significant increase in domestic and international pressure.

South Africa and Chile share painful recent histories that have strained the fabric of their societies. But the future looks brighter in many respects and their health sectors will play major roles as economic development unfolds.

\section{CONCLUSION}

Both countries share similar:

1. Dual public/private health system

2. Implementation of new health care reforms.

3. A focus in primary care health in their public health system.

4. World Bank classification as middle income economies.

5. Huge inequities in income distribution. Now both countries share income inequality instead of racial inequality.

\section{References}

1. Pan American Organization, PAHO. Health in the Americas: 2002 edition. Washington D.C., 2002. p.152-167. 2. Soderlund N, Schierhout G, van den Heever A. Private Health Sector Care. In: Ntuli A, editor. South African Health Review 1998. Durban: Health Systems Trust; 1998. Retrieved from http://www.hst.org.za/sahr/98/chap13.htm, on March 19, 2004.

3. Masobe, P., Van den Heever M. The South African Health System: A Historical Review and Options for the Future, 2002. Retrieved from

http://www.aim-mutual.org/docs/masobe_en.pdf on March 3, 2004.

4. Benatar, SB, Health care reform and the Crisis of HIV and AIDS in South Africa. The New England Journal of Medicine. 2004; 351(1); 81-92.

5. Silva Rojas P. Sistema de Salud de Chile. Cuadernos MÃicos Sociales. 1998; XXXIX, 1, 46-53.

6. Cruz Coke R. History of the Chilean Medicine. Santiago: Editorial AndrÃ Bello, 1995, p.147- 152, 474 - 486.

7. Barrientos A and Lloyd-Sherlock P .Reforming health insurance in Argentina and Chile. Health policy and planning. 2000; 15(4): 417-423.

8. AFP Association. The Chilean AFP System Provides Most Space for Development of APV, 2003. Research Series. 38: Dec. Retrieved from

http://www.afp-ag.cl/ingles/estudios/DesarrolloAPV.pdf , on October 19, 2004.

9. Leon F, Correa M, Hern Ãdez T, and Weintraub M. The case of the Chilean health system, 1983-2000. 1999; 
Retrieved from

http://www.paho.org/English/HDP/HDD/20Fran.pdf, on March 12, 2004.

10. Ministerio de Salud de Chile, MINSAL. Documento para la aplicaci $\tilde{A}$ del sistema AUGE en las redes de atenci $\tilde{A}$ del Sistema Nacional de Servicios de Salud. 2004; Retrieved from

http://www.minsal.cl/ici/doc_reforma/pilotoauge19-4-04.pdf , on June 30, 2004

11. United Nations. United Nations Development Program, Human Development Report 2004. Retrieved from http://hdr.undp.org/reports/global/2003/pdf/hdr03_HDI.pdf , on June 30, 2004

12. World Heath Organization .Core Indicators. 2004.

Retrieved from http://www.who.int/country/chl/en/, on June 30, 2004.

13. World Heath Organization .Core Indicators. 2004.

Retrieved from http://www.who.int/country/zaf/en/ , on June 30, 2004.

14. Lit PK. Equity in Health care in Developing countries. 2002. Retrieved from

http://phuakl.tripod.com/eTHOUGHT/healthequity.doc , on February 27, 2004.

15. World Bank. Chile Data Profile. 2004. Retrieved from http://devdata.worldbank.org/external/CPProfile.asp?Selecte $\mathrm{dCountry}=\mathrm{CHL} \& \mathrm{CCODE}=\mathrm{CHL} \& \mathrm{CNAME}=\mathrm{Chile} \& \mathrm{PTYPE}$ $=\mathrm{CP}$, on March 12, 2004.

16. World Bank. South Africa Data Profile. 2004. Retrieved from

http://devdata.worldbank.org/external/CPProfile.asp?Selecte dCountry=ZAF\&CCODE $=$ ZAF\&CNAME $=$ South $\% 2 B$ Afric a\&PTYPE=CP, on March 12, 2004.

17. Vega J, Jadue L, Delgado I, Burgos R, Brown F, and F Marin. Disentangling the pathways to health inequities: The Chilean health equity gauge. 2002. Retrieved from http://www.paho.org/English/HDP/Equity-Chile.pdf. , on March 12, 2004

18. Armans, GA. Decentralization of health care and medical teaching: the Chilean experience. Rev Med Chile. 2003. July; 131(7): 788-98.

19. South African Health Review, (SAHR). 2003. Retrieved from http://www.healthlink.org.za/sahr/2002/ on June 30, 2004.

20. McIntyre D, Gilson L. "Putting Equity in Health Back onto the Social Policy Agenda: Experience from South
Africa." Social Science Medicine June. 2002; 54(11): 1637-56.

21. De Beer C, Broomberg J, Financing health care for all: Is national health insurance the first step? South African Medical Journal. 1990; 78(3):144-147.

22. South Africa info. The official gateway, Health care in South Africa. 2004. Retrieved from

http://www.safrica.info/ess_info/sa_glance/health/health.htm , on June 30, 2004.

23. Blaauw D, Penn-Kekana L. Socio-Economic inequalities and maternal health in South Africa. 2000. Retrieved from http://www.wits.ac.za/chp/b46.pdf, on March 03, 2004. 24. Jewkes R, Vundule C, Maforah F, and Jordaan E.

Relationship dynamics and adolescent pregnancy in South

Africa. Social Science and Medicine. 2001; 52 (5): 733-744. 25. Hollstein RD, Vega J, and Carvajal Y. Social inequalities and health: Socioeconomic level and infant mortality in Chile in 1985-1995. Rev Med Chile. 1998. March, 126(3): 333-340.

26. World Health Organization. The world health report 2000, Health systems: Improving performance. Geneva, Switzerland, 2000.

27. Murray C, Kreuser J, and Whang W. Cost-effectiveness analysis and policy choices: investing in health systems. Bulletin of the World Health Organization. 1994; 72(4): 663-674.

28. Lovelife, 2000. The impediment catastrophe: a resource book on the emerging HIV/ AIDS epidemic in South Africa. Retrieved from www.lovelife.org.za, on March 3, 2004.

29. De Rosario, JM. Healthcare system performance indicators: a new beginning for a reformed Canadian healthcare system. Journal Health Quality. 1999; 21: 3741. 30. National Association of Pre Paid Health Plans.

ISAPRES, the private health sector in Chile.2003. Retrieved from http://www.isapre.cl/documentos/isapre.en.pdf, on June 30,2004

31. Joint United Nation Program on HIV/AIDS (UNAIDS). 2004. Retrieved from http://www.unaids.org/Unaids, on June 30, 2004

32. Day C, Gray A. Health and related indicators. In: South Africa Heath Review 2001.Durban, South Africa: Health System Trust.

33. Makgoba MW. Politics, the media and science in HIV/AIDS: the perils of pseudoscience. Vaccine, 2002; 20: 1889-1904. 


\section{Author Information}

Alberto Coustasse, MD, Dr.PH.

Research Associate, Office of the Dean, School of Public Health, University of North Texas Health Science Center

Peter Hilsenrath, Ph.D.

Professor, Health Management and Policy Department, School of Public Health, University of North Texas Health Science Center

Patricio Silva Rojas,

,, School of Public Health, University of Chile 